\title{
THE EFFECT OF PHYSICAL EXERCISE WITH IRON AND WITHOUT IRON ON HEMOGLOBIN CONTENT AND MAXIMUM AEROBIC CAPACITY
}

\author{
Umar, Yanuar Kiram, Alex Aldha Yudi \\ umarkepel@fik.unp.ac.id, yanuar@fik.unp.ac.id, alexaldha@fik.unp.ac.id
}

\begin{abstract}
Abstrac
This study aims to analyze how physical exercise with iron and no iron intake affect the hemoglobin level and maximum aerobic capacity. The hemoglobin level and maximum aerobic capacity will actually be affected either by iron intake or by physical exercises. The population is the students ofFaculty of Sports Science Universitas Negeri Padang, Sports Coach program class of 2015/2016, and were registered in the semester of July December 2017. The samples are 30 male students. The study was conducted at the Fitness Laboratory of Faculty of Sports Science Universitas Negeri Padang. The treatments of the research are in the form of physical exerciseswhich are circuit training and HIIT for 16 times exercises, then giving Ferizz brandiron supplements in tablet. The instruments to measure hemoglobin levels are using the hemoglobin testing system, quik-check, and Bleep Test to measure maximum aerobic capacity. Data analysis using $t$ test and anova.The results show that all hypotheses proposed in this research are acceptable; $\mathrm{p}<\alpha 0.05$.

Thus it is expected that this research is useful for interested parties, especially in order to improve the physical ability of athletes, so that maximum achievement in every competition can be reached.
\end{abstract}

Keywords; Physical Exercise, Iron Intake, Hemoglobin, Maximum Aerobic Capacity.

\section{INTRODUCTION}

Maximum aerobic capacity or commonly called VO2 max, is a physical element associated with the body's ability to consume oxygen maximally permenit. The use of permenite oxygen is necessary for chemical processes to produce aerobic energy in the cells of the body that is active. Much of the oxygen used depends on the severity of physical activity and the availability of oxygen in the tissues. Maximum oxygen availability in the tissues is affected by the vital capacity of the lung and hemoglobin levels in the blood, because according to its function, hemoglobin will bind the oxygen molecules present in the lungs and carry them throughout the body's tissues. Hemoglobin levels in red blood cells vary, and are influenced by many factors. Among the factors that may affect hemoglobin levels are; amount of iron, physical activity, rest period, menstruation and injury that cause bleeding. Iron deficiency can cause hemoglobin levels in red blood cells to drop below normal levels. This low hemoglobin level is called anemia. Anemia can cause the number of oxygen molecules that can be transported by hemoglobin to the tissues of the body tissue to be reduced, so the availability of oxygen in each cell also becomes less and not enough to support the 
aerobic metabolism process maximally, this can result in low level of personat, will quickly experience fatigue during light activity though.

In sports branches that require tripatahan as its main physical component, the maximum aerobic capacity (VO2 max) is an absolute requirement that an athlete must have if it is to perform optimally, since maximal aerobic capacity is a physical element capable of providing maximum oxygen for the need for aerobic energy metabolism processes. If a person's aerobic capacity is low, then the aerobic energy metabolism process is also low, so the energy available to perform the activity for a long time is also low or small, consequently a person will quickly experience fatigue. In line with the above, the high and low aerobic capacity of a person, one of which is influenced by hemoglobin levels, whereas normal or not one's hemoglobin levels, one of which is influenced by the amount of iron in the blood and the amount of iron is influenced by nutrient intake, menstruation, because at the time of menstruation, a woman will bleed indirectly also will decrease levels of iron available in the blood, so indirectly also will affect the hemoglobin level.

This study aims to see the effect of physical exercise with iron and iron intake on hemoglobin and aerobic capacity. Hopefully the results of this study are useful for the parties concerned, especially for athletes and coaches in terms of achieving maximum in sports.

\section{Maximum Aerobic Capacity (VO2 max)}

Maximum aerobic capacity refers to the maximum amount of oxygen that an individual can take advantage of during an intensive or maximum exercise. It is measured as milliliters of oxygen used in one minute per kilo gram of body weight. Kapasiatas aerobik maximum is also called as "the ability of the body to consume oxygen maximally permenit". This means how much the body uses the oxygen needed for the process of oxidation permenit. Meanwhile, according to Churchill Livingstone (2006) that;

"Maximum oxygen uptake (V02 max) can be defined as the highest level at which oxygen can be extracted, transported and consumed for the aerobic ATP synthesis process. Typically, maximal aerobic capacity is expressed in milliliters of oxygen per kilogram of body weight per unit of time (ie, mL.kg-1.min-1.) ". Meanwhile, according to Scott and Edward (2009) that; "Maximum aerobic power (V02max), is a measure of the reproducibility of the capacity of the cardiovascular system to deliver oxygenated blood to the large muscle mass involved in dynamic work".

Meanwhile, Elizabeth Quinn (2011) says that; "VO2 max, or maximal oxygen uptake, is one factor that can determine athlete's capacity to perform sustained exercise and is linked to aerobic endurance". Can be interpreted that; VO2 max, or maximal 
oxygen uptake, is one factor that can determine the capacity of an athlete to perform continuous and related exercises for aerobic endurance.

Meanwhile Sharkey J Brian (2003) says that; "Aerobic fitness, defined as the maximum capacity to inhale, channel and use oxygen, should be measured in laboratory tests called maximal oxygen intake (or VO2 max)".

A number of studies have shown that maximal aerobic capacity is strongly associated with performance requiring payday. This is as stated by T. Meyer (2003) that; Maximal oxygen uptake (VO2 max) is a parameter that is commonly used to describe the capacity of endurance).

In addition to supporting the aerobic metabolism process (oxidation), maximum aerobic capacity is also required for recovery (recovery). Because after all, after a long and heavy activity, the supply of ATP in the active muscle cell is so low that is insufficient to generate energy for muscle contraction, so the ATP resinthesis process needs to be done. The ATP resinthesis process requires energy derived from creatine phosphate (CP), anaerobic glucose and aerobic glucose and fat (oxidation). In order for the oxidation process, oxygen is required. To supply oxygen to muscle cells requires blood (hemoglobin) as transport.

Meanwhile Scott and Edward (2009) state that;

High maximal aerobic capacity (VO2 max) allows for more repetitive and longer motion, than when the maximum aerobic capacity is low. For the same dose of physical activity, higher maximal aerobic capacities will result in lower lactic acid levels. For people who regularly perform repetitive physical activities, the maximum aerobic capacity will be better than the people who usually sit more and sit quietly in pursue work.

Thus it can be concluded that; the longer we do the activity, the more we need energy, thus demanding a high aerobic process in order to generate a lot of energy. The low aerobic process depends on the high level of capability of a person's maximum aerobic level.

\section{Physical training}

Physical exercise is an activity that someone does to improve or maintain body fitness. Physical exercises are generally grouped into several categories, depending on the effect it has on the human body. Http: //id.wikipedia.org/wiki/Physical Exercises.

Exercise is a physical activity that must be done to improve physical skills, techniques, tactics / strategies and mental. How the form of physical exercise to be performed, depending on the goal to be achieved. To achieve the intended purpose, the training program should be arranged in such a way as to the practice sessions.

Meanwhile Harsono (1996), said that; exercise is a systematic practice that is done repeatedly to achieve the desired goals. ". For the purpose of training can be achieved in accordance with the desired, it must refer to the principles of practice. 
According to Bompa; "The principles of practice consist of; specialization, individualization, model development exercises and increased loading ". According to Fleck, S. (2004) in Bompa that; Specialization is that exercise forms should refer to sports that involve motion patterns, metabolic needs, exertion patterns, muscle contraction types and mobility-driven movement.

\section{Hemoglobin}

Hemoglobin is a protein molecule in red blood cells that serves as a transport medium of oxygen $(\mathrm{O} 2)$ from the lungs to the entire body tissues and carries carbon dioxide (CO2) from the body's tissues back to the lungs. (Sacher and Mc Phearson, 2004). Structurally, hemoglobin consists of one globin protein and four iron, each iron will bind 1 molecule of oxygen (O2), so normally, for one molecule hemoglobin can bind and carry four molecules of oxygen. (Astrand, 1986). This is as Sherwood (2001) says; The hemoglobin molecule consists of two parts: 1. the globin part, a protein formed from four highly polypeptide chains, and 2. an iron-containing non-ferrous nitrogenous group known as the hem group, each attached to one polypeptide. Each iron atom can bind reversibly with one molecule of 02 ; thus, every molecule of hemoglobin can carry four passengers 02 . Hemoglobin levels of people with one another is difficult to distinguish because affected by race, gender, age, an

Table 1. Hemoglobin levels by sex

\begin{tabular}{|l|c|}
\hline \multicolumn{1}{|c|}{ Woman } & $12-16 \mathrm{gr} / \mathrm{dl}$ \\
\hline Man & $14-18 \mathrm{gr} / \mathrm{dl}$ \\
\hline Child & $10-16 \mathrm{gr} / \mathrm{dl}$ \\
\hline Newborn baby & $12-24 \mathrm{gr} / \mathrm{dl}$ \\
\hline
\end{tabular}

\section{METHOD}

This type of research is quasi experiment method. This research was conducted in the laboratory of Faculty of Sport Science State University of Padang. The process of collecting research data is done in 2 (two) main stages. The first stage of data collection on hemoglobin levels and maximum aerobic capacity. The second stage is the provision of physical exercise with iron and iron without as much as 16 times the exercise, (3 times per week).The population in this study, are students of the Faculty of Sport Sciences State University of Padang, Sport Science 2015/2016 programs registered in the semester of July - December 2017. 
While the sample used in this study as many as 30 students with a purposive sampling technique. From 30 people are divided into 2 groups, each group consists of 15 people sample.

\section{Research Instruments}

Instruments used to collect data are; 1. Maximum Aerobic Capacity The instrument used to measure maximum aerobic capacity is the Bleep Test. The shape of the Bleep test can be seen in the picture below.

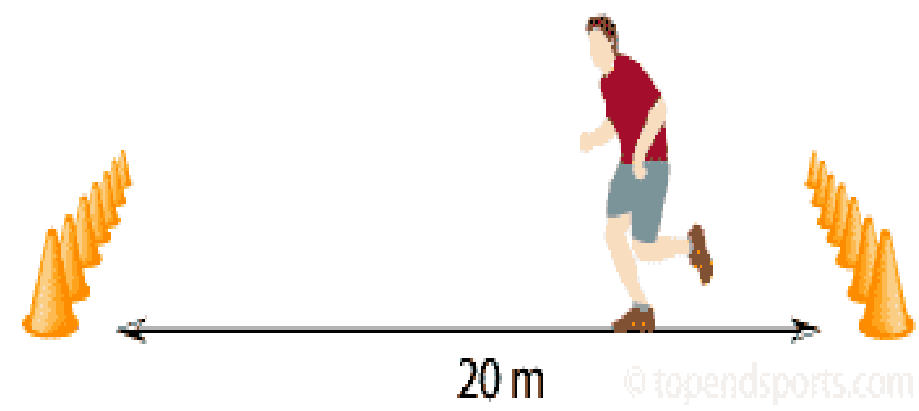

Figure 2. Maximum Aerobic Capacity instrument with Bleep test.

The instrument used to measure hemoglobin level is $\mathrm{Hb}$ hemoglobin testing system, quik-check brand. The form of some of these tools can be seen in the picture below;
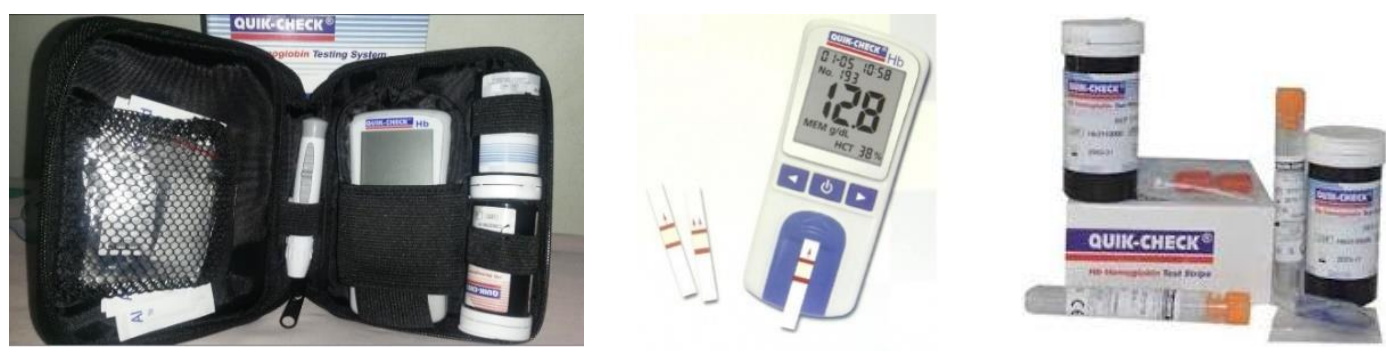

Figure 3. Hb hemoglobin testing system quik-check, supporting inatruments.

Statistical analysis used in this study consists of; Descriptive statistics that serve to describe or provide an overview of the object under study through the sample data or population as it is, without doing the analysis and make conclusions that apply to the public and inferential statistics using $t$ and anova at significance level $\alpha 0.05$.

\section{RESULTS}

\section{The first hypothesis}

The first hypothesis reads: Physical exercise with iron intake significantly affects the maximum aerobic capacity. Based on the results of data analysis obtained 
value $\rho=0.002<\alpha 0.05$. Thus it can be concluded that there is the influence of physical exercise with iron intake of maximum aerobic capacity. For more details can be seen in the following table;

Table 2. $t$ test results of initial and final data of Maximum Aerobic Capacity Group 1 with iron intake

\begin{tabular}{|c|c|c|c|c|c|c|c|c|c|}
\hline \multicolumn{7}{|c|}{ Paired Differences } & \multirow[b]{3}{*}{$\mathrm{t}$} & \multirow[b]{3}{*}{$\mathrm{df}$} & \multirow[b]{3}{*}{ Sig. (2-tailed) } \\
\hline & & \multirow[b]{2}{*}{ Mean } & \multirow{2}{*}{$\begin{array}{c}\text { Std. } \\
\text { Deviation }\end{array}$} & \multirow{2}{*}{$\begin{array}{c}\text { Std. Error } \\
\text { Mean }\end{array}$} & \multicolumn{2}{|c|}{$\begin{array}{l}\text { 95\% Confidence } \\
\text { Interval of the } \\
\text { Difference }\end{array}$} & & & \\
\hline & & & & & Lower & Upper & & & \\
\hline Pair 1 & $\begin{array}{l}\text { KAM Awal- } \\
\text { KAM Akhir } \\
\text { Kelompok } 1\end{array}$ & -.12667 & 2.19755 & .56741 & -1.34363 & 1.09030 & -.223 & 14 & .002 \\
\hline
\end{tabular}

\section{Second Hypothesis}

The second hypothesis reads; "Physical exercise without iron intake significantly affects the maximum aerobic capacity. Based on the results of data analysis obtained value $\rho=0.001<\alpha 0.05$. Thus it can be concluded that there is the effect of physical exercise without iron intake of maximum aerobic capacity. For more details can be seen in the following table;

Table 3. Test results of initial and final data of Maximum Aerobic Capacity Group without iron intake

\begin{tabular}{|c|c|c|c|c|c|c|c|c|c|}
\hline \multicolumn{7}{|c|}{ Paired Differences } & \multirow[b]{3}{*}{$\mathrm{t}$} & \multirow[b]{3}{*}{$\mathrm{df}$} & \multirow[b]{3}{*}{ Sig. (2-tailed) } \\
\hline & & \multirow[b]{2}{*}{ Mean } & \multirow{2}{*}{$\begin{array}{c}\text { Std. } \\
\text { Deviation }\end{array}$} & \multirow{2}{*}{$\begin{array}{c}\text { Std. Error } \\
\text { Mean }\end{array}$} & \multicolumn{2}{|c|}{$\begin{array}{l}\text { 95\% Confidence } \\
\text { Interval of the } \\
\text { Difference }\end{array}$} & & & \\
\hline & & & & & Lower & Upper & & & \\
\hline Pair 1 & $\begin{array}{l}\text { KAM Awal- } \\
\text { KAM Akhir } \\
\text { Kelompok } 2\end{array}$ & -.12000 & 2.56660 & .66269 & -1.54133 & 1.30133 & -.181 & 14 & .001 \\
\hline
\end{tabular}

\section{The third hypothesis}

The third hypothesis reads; "Physical exercise with iron intake has a significant effect on hemoglobin levels. Based on the results of data analysis obtained value $\rho=0.002<\alpha 0.05$. Thus it can be concluded that there is the effect of physical exercise with iron intake on hemoglobin levels. For more details can be seen in the following table; 
Table 4. Result of t test of initial and final data Hemoglobin level Group 1 with iron intake

\begin{tabular}{|c|c|c|c|c|c|c|c|c|c|}
\hline \multicolumn{7}{|c|}{ Paired Differences } & \multirow[b]{3}{*}{$\mathrm{t}$} & \multirow[b]{3}{*}{ df } & \multirow[b]{3}{*}{ Sig. (2-tailed) } \\
\hline & & \multirow[b]{2}{*}{ Mean } & \multirow{2}{*}{$\begin{array}{c}\text { Std. } \\
\text { Deviation }\end{array}$} & \multirow{2}{*}{$\begin{array}{c}\text { Std. Error } \\
\text { Mean }\end{array}$} & \multicolumn{2}{|c|}{$\begin{array}{l}95 \% \text { Confidence } \\
\text { Interval of the } \\
\text { Difference }\end{array}$} & & & \\
\hline & & & & & Lower & Upper & & & \\
\hline Pair 1 & $\begin{array}{l}\text { Kadar Hb } \\
\text { Awal-Akhir } \\
\text { Kelompok } 1\end{array}$ & -.14667 & .36814 & .09505 & -.35053 & .05720 & -1.543 & 14 & .000 \\
\hline
\end{tabular}

\section{Fourth hypothesis}

The fourth hypothesis reads; "Physical exercise without iron intake has a significant effect on hemoglobin levels. Based on the results of data analysis obtained value $\rho=0,000<\alpha 0,05$. Thus it can be concluded that there is the effect of physical exercise without iron intake on hemoglobin levels. For more details can be seen in the following table;

Table 5. Result of $t$ test of initial and final data Hemoglobin level Group 2 without iron intake

\begin{tabular}{|c|c|c|c|c|c|c|c|c|c|}
\hline \multicolumn{7}{|c|}{ Paired Differences } & \multirow[b]{3}{*}{$\mathrm{t}$} & \multirow[b]{3}{*}{ Df } & \multirow[b]{3}{*}{ Sig. (2-tailed) } \\
\hline & & \multirow[b]{2}{*}{ Mean } & \multirow{2}{*}{$\begin{array}{c}\text { Std. } \\
\text { Deviation }\end{array}$} & \multirow{2}{*}{$\begin{array}{c}\text { Std. Error } \\
\text { Mean }\end{array}$} & \multicolumn{2}{|c|}{$\begin{array}{l}\text { 95\% Confidence } \\
\text { Interval of the } \\
\text { Difference }\end{array}$} & & & \\
\hline & & & & & Lower & Upper & & & \\
\hline Pair 1 & \begin{tabular}{|l} 
Kadar Hb \\
Awal-Akhir \\
Kelompok 2
\end{tabular} & .11333 & .45019 & .11624 & -.13597 & .36264 & .975 & 14 & .000 \\
\hline
\end{tabular}

\section{The fifth hypothesis}

The fifth hypothesis reads; "There is a difference in the effect of physical exercise between being given iron intake with no iron intake to hemoglobin and maximum aerobic capacity. Based on the results of data analysis obtained value $\rho=0,000<\alpha 0,05$. Thus it can be concluded that there is a difference of influence between physical exercise with iron and iron intake without the maximum aerobic capacity and hemoglobin level. For more details can be seen in the following table; 
Table 6. Anovadata end test results Maximum Aerobic Capacity and Group 1 and Group 2 hemoglobin levels

\begin{tabular}{|c|c|c|c|c|c|}
\hline \multicolumn{6}{|l|}{ ANOVA } \\
\hline & Sum of Squares & $\mathrm{df}$ & $\begin{array}{l}\text { Mean } \\
\text { Square }\end{array}$ & $\mathrm{F}$ & Sig. \\
\hline Between Groups & 13391,521 & 3 & 4463,840 & 454,834 & ,000 \\
\hline Within Groups & 549,596 & 56 & 9,814 & & \\
\hline Total & 13941,117 & 59 & & & \\
\hline
\end{tabular}

\section{DISCUSS}

Based on the results of data analysis, it turns out all the hypothesis proposed in this study can be accepted truth. The treatment provided in the form of physical exercise as well as iron intake and without iron giving both have a significant effect on maximal aerobic capacity and hemoglobin levels.

Increased maximum aerobic capacity in both groups after treatment was given physical exercise, as the exercise program was designed according to the training program to increase maximum aerobic capacity. The training program is given to the sample in the form of circuit training and high intensity interval training called HIIT (High Intensity Interval Training). Circuit training consists of 6 posts, where each post is a form of exercise that spurs the work of the organs associated with a maximum increase in aerobic capacity such as heart, lungs and skeletal muscle. The forms of exercise in each post are like; runs, sit-ups, shuttle runs, push-ups, zigzagging and squat trush. The forms of the exercises in each post are always varied in the next training sessions.

Meanwhile, the exercise material to run the interval with high intensity, performed on track (track). The form of training is sprinting from 0-100 meters, 100 to 200 meters jogging, 200 to 300 sprints again and from 300 to 400 meters jogging. This high intensity interval exercise (HIIT) is very effective for increasing maximum aerobic capacity (VO2 max). This is as said by Roger Schmitz (2013) that; Research has shown that HIIT dramatically improves $\mathrm{VO}_{2}$ max and other exercise performance capabilities in athletes who rely on aerobic energy metabolism for their chosen sport. In addition, HIIT is shown to directly improve exercise performance in real situations. Studies have shown that HIIT dramatically increases VO2 max and other exercise performance capabilities in athletes who rely on aerobic energy metabolism for their sport of choice. In addition, HIIT is shown to directly improve sports performance in real situations, as shown in laboratory tests that simulate bicycle races lasting between 2 minutes to an hour.

Research on HIIT conducted by Dr., Tabata in 1996 about; Effects of moderateintensity endurance and high-intensity intermittent training on anaerobic capacity and VO2max. The results of this study conclude that increased maximal aerobic capacity 
(VO2 max) as the effect of high intensity interval training is due to increased arganorgans affecting maximum aerobic capacity (VO2 max) ie;

The size and strength of your heart -- the volume of blood it can pump through out your body to deliver $\mathrm{O}_{2}$ and glucose. Blood also carries away byproducts: $\mathrm{CO}_{2}$ and lactate. The size and strength of blood vessels. The number of capillaries - to enable more bandwidth for the blood to get to where it needs to go to perform the nutrient exchanges (fun fact - a significant portion of hypertrophy is due to capillary density). Increased capillary density in the lungs and number of alveoli to perform the gas exchanges.

Based on the above quotation it can be concluded that, by doing high intensity interval training will increase the maximum aerobic capacity (VO2 max), this is caused by the increasing size and strength of heart, so that the volume of blood pumped to all body that carry oxygen also increase. The increased size and strength of the blood vessels include the amount of capillaries and the amount of blood that will carry nutrients and oxygen, and the increased amount of capillaries in the pulmonary alveolus that will enhance the gas exchange process.Furthermore, the relationship of iron and hemoglobin as well as the maximum aerobic capacity. It is said that for the production of red blood cells in which hemoglobin contains iron is required. It is as described by the University of California that; Iron is an essential element for blood production. About 70 percent of your body's iron is found in the red blood cells of your blood called hemoglobin and in muscle cells called myoglobin. Hemoglobin is essential for transferring oxygen in your blood from the lungs to the tissues. (https://www./ hemoglobinandfunctionsofiron/).

Iron is an essential ingredient for blood production. About 70 percent of your body's iron is found in your blood red blood cells called hemoglobin and in muscle cells called myoglobin. Hemoglobin is very important for transferring oxygen into your blood from the lungs to the tissues.

Based on the above quotation it can be concluded that, the more iron available in the body, the higher the hemoglobin level, so that more oxygen can be transferred throughout the body for energy metabolism, so that more energy is generated and ultimately aerobic space can also increase. Thus, overall it can be concluded that, physical exercise either in the form of interval training with high intensity as well as the form of bias circuit training increase maximum aerobic capacity, because the physical activity of these forms of exercise will spur the body organs such as; heart, lungs, blood vessels and skeletal muscle, so this condition will obviously increase the maximum aerobic capacity, because it is the organs of the body that will directly affect the low maximum aerobic capacity of a person.

In addition, another component that will affect the maximum aerobic capacity is blood quality, in this case is the hemoglobin level, because the hemoglobin that will transport oxygen from the lungs throughout the body for metabolic processes produces energy to 
be used during physical activity. Meanwhile, high levels of one's hemoglobin will be influenced by the amount of iron available in the body.

\section{CONCLUSIONS}

Based on the results of data analysis in Chapter V, it can be concluded that; Physical exercises whether given iron intake or without iron are equally able to increase maximum aerobic capacity, and do not have a considerable effect on hemoglobin levels between groups given iron intake and groups not given iron intake, this is likely the quality of the ingredients food consumed outside the research process is sufficient. In addition, the student of the Faculty of Science Faculty of State University of Padang, is familiar with physical activity because of the hours of sports practice classes.

\section{REFERENCES}

Astrand et al, 1986. Textbook of Work Physiology. Fourth ed. USA: Human Kinetics

Bompa, Haff, G.G, 2009.Periodization Theory and Methodology of Training. Fifth ed. Champaign: Human Kinetics.

Cunningham, FG, et, al.ObstetriWilliam, edisi21.Jakarta:EGC;2006

Churchill Livingstone, 2006. Advances inSport and Exercise Sience Series. The Physiology of Training, Philadelphia: Elsevier Limited.)

Donald Ary., Luchy C.Jacobs dan Asghar R, 2004.Pengantar Penelitian dalam Pendidikan, Yogyakarta: Pustaka Pelajar offset.

Elizabeth Quinn, 2011.VO2 Max - Definition. http://sportsmedicine.about.com/od/anatomyandphysiology/a/VO2_max.htm

--------, 2011. What Is $\mathrm{VO}_{2}$ Max?.http://sportsmedicine.about.com/old/anatomy and physiology/a/VO2_max.htm.

Fox.E.L. et al.,1988. The Physiological Basis of Physical Education and Athletics Philadelphia: Sauders College publishing.

Fungsi Hemoglobin Bagi Tubuh http://caratipskesehatan.com/fungsi-hemoglobin$\underline{\text { bagi-tubuh/Posted in Kesehatan A-Z By Haniva-khun On Desember 16, } 2014}$

Garrow JS dan James WPT. 1993. Human Nutrition and Dietetics, Ninth Edition.

Edinburgh: Churchill Livingstone. Page 174-180.

Hairy Junusul. 2010.Dasar-dasar Kesehatan Olahraga. Jakatra: Univerasitas Terbuka,. Harsono. Prinsip dan Metodologi Pelatihan, Jakarta: PIO-KONI Pusat,1996.

https://www.google.co.id/search?q=contoh+model+latihan+bermain.

https://www.google.co.id/search?q=contoh+model+latihan+sirkuit. 
Johny Lycholat, 1989 Circutit Weight Training (Northamptonshire: Thorsons Publishing Group.

Mackenzie B.2005.101Performance Evaluation Tests, London: Electric Word plc..

Roger schmitz, 2013. How to Increase VO2 max with HIIT, http://my.moxy monitor.com/blog/bid/259385/How-to-Increase-VO2-max-with-HIIT

SacherR. McPherson R. 2004.Tinjauan Klinis Hasil Pemeriksaan Laboratorium, EGC, Edisi 11, Cetakan 1 Hal 33

Scott dan Edward, 2009.Exercise Physiology, Fitness and Performance (New York: McGraw-Hill Higher Education,)

Schmolinsky, Gerhardt, 1983. Track and Field. Text Book For Coaches And Sports Teachers.UK: Sportvorlag.

Sharkey J Brian, 2003.Kebugaran Kesehatan (Jakarta: PT. Raja Grafindo Persada,

Tabata, 1996. Effects of moderate-intensity endurance and high-intensity intermittent training on anaerobic capacity and VO2max, https://www.quora.com/How-canHIIT-improve-VO2-max.

T. Meyer . et al.,2003.Maximaloxygen uptake during field running does not exceed that measured during treadmill exercise. Eur J Appl Physiol, hh. 88: 387-389

Wilmore JH and DL. Costill, 2005. Physiology of Sport and Exercise: 3rd Edition Champaign: IL Human Kinetics.

http://www.hasbihtc.com/pengertian-dan-fungsi-lengkap-hemoglobin.html, Publish on June 7, 2012 4:29 pm under Artikel, Kesehatan by hasbihtc

http://manfaatnyasehat.blogspot.co.id/2013/06/sumber-zat-besi.html

http://www.sridianti.com/struktur-dan-fungsi-hemoglobin.htmlBudipada 28 February, 2016

http://www.carakhasiatmanfaat.com/artikel/manfaat-zat-besi-bagi-kulit-rambut-dan-

kesehatan.html

https://id.wikipedia.org/wiki/Latihan_fisik

https://id.wikipedia.org/wiki/Sirkuit_latihan

https://www.ucsfhealth.org/education/hemoglobin_and_functions_of_iron/

University of California San Francisco2017 
